\title{
PIOTR DEHNEL*
}

\section{WERYFIKACJONIZM WITTGENSTEINA}

\begin{abstract}
WITTGENSTEIN'S VERIFICATIONISM

The paper explores Wittgenstein's discourse of 1929-1930 concerning the problem of verification in respect of both its textual sources and its significance. I first discuss the most important interpretations of the issue and then analyze Wittgenstein's notes from that period along with his conversations with Schlick and Waismann. The results of the analysis imply that the empirical sense of verification intertwines with its grammatical sense. On the one hand, the question of verification appears in the context of phenomenology and so-called phenomenological language, referring to immediate experience; on the other hand, it is conceived of as a means of settling the sense of a sentence, or, which amounts to the same thing, of fixing the available uses of a sentence. Such an ambiguity is characteristic of the middle, transitory period of Wittgenstein's philosophical development.
\end{abstract}

Keywords: verification, Wittgenstein, language, proposition, sense, phenomenology, grammar

Według członków Koła Wiedeńskiego autorem zasady weryfikacji był Ludwig Wittgenstein. Na jego autorytet powoływali się Friedrich Waismann (1930: 228) i Moritz Schlick (1969: 340). Wprost na autorstwo Wittgensteina wskazywał Rudolf Carnap w swej Intellectual Autobiography, pisząc:

Pogląd, że te zdania i pytania [zdania i pytania metafizyki - P. D.] nie mają treści poznawczej, opiera się na zasadzie weryfikowalności Wittgensteina. Zasada ta głosi po pierwsze, że znaczenie zdania dane jest za sprawą warunków jego weryfikacji, a po drugie, że zdanie jest sensowne wtedy i tylko wtedy, gdy jest z zasady weryfikowalne, to znaczy, kiedy istnieją możliwe - niekoniecznie rzeczywiste - okoliczności, które jeśli zajdą, to ustanowią w sposób definitywny prawdziwość zdania. Zasadę weryfikowalności zastąpiono później bardziej liberalną zasadą potwierdzalności (Carnap 1963: 44).

* Dolnośląska Szkoła Wyższa we Wrocławiu, ul. Strzegomska 55, 53-611 Wrocław; Akademia Sztuk Pięknych we Wrocławiu, Pl. Polski 3/4, 50-156 Wrocław, e-mail: piotr.dehnel@dsw.edu.pl, ORCID: oooo-0002-6958-6148. 
Niektórzy badacze mówią o weryfikacjonistycznym okresie w filozofii Wittgensteina (por. Hacker 1986: 134, Monk 2003: 312), a nawet twierdzą, że około 1929 r. „głosił weryfikacjonizm w najbardziej skrajnej postaci” (Wrigley 1989: 265). Problem jest ważny nie tylko z uwagi na związki między stanowiskiem Wittgensteina widocznym w Traktacie logiczno-filozoficznym a poglądami przedstawicieli Koła Wiedeńskiego, czyniących z zasady weryfikacji główną oś, wokół której obracała się cała ich filozofia i która sprawiała zarazem poważne trudności (por. Misak 2005, Koterski 2001). Na uwagę zasługuje również rola weryfikacji w wewnętrznym rozwoju myśli Wittgensteina, a w szczególności jej znaczenie dla uchwycenia i opisu przejścia do późnej fazy jego filozofii.

Celem artykułu jest próba odpowiedzi na pytanie o źródła i sens Wittgensteinowskiego weryfikacjonizmu z lat 1929-1931. Był to czas nie tylko powrotu Wittgensteina do filozofii i ponownego namysłu nad zawiłymi kwestiami Traktatu, lecz także narodzin nowych idei. W jego notatkach z tego okresu które obok zapisów rozmów ze Schlickiem i Waismannem stanowić będą główny przedmiot moich analiz - znajdziemy enigmatyczną nieco uwagę: „Traktuję swoją obecną pracę prowizorycznie - jako środek do celu" (Ms 106: 1)1. Tym celem była książka znana dziś jako Dociekania filozoficzne. Starając się więc wydobyć właściwy sens wypowiedzi Wittgensteina na temat weryfikacji, trzeba pamiętać, że jego ustalenia nie były ostateczne ani pewne, a cel nie przybrał jeszcze właściwego wyrazu.

\section{1. ŹRÓDłA}

\subsection{KOŁO WIEDEŃSKIE}

Można by zapytać, na które konkretnie twierdzenia Wittgensteina powoływali się filozofowie Koła Wiedeńskiego, przypisując mu autorstwo zasady weryfikacji. Odpowiedzi należy szukać w tekstach Waismanna, który po raz pierwszy sformułował tę zasadę w artykule Logische Analyse des Wahrscheinlikeitsbegriffs:

Zdanie opisuje pewien stan rzeczy. Stan rzeczy istnieje albo nie. Czegoś pośredniego nie ma i dlatego nie ma też przejścia między prawdą a fałszem. Jeśli nie można w żaden sposób ustalić, kiedy zdanie jest prawdziwe, to nie ma ono w ogóle żadnego sensu; albowiem sensem zdania jest metoda jego weryfikacji. W istocie ten, kto wypowiada jakieś zdanie, musi wiedzieć, w jakich warunkach nazwie on to zdanie prawdziwym albo fałszywym (Waismann 1930: 228).

${ }^{1}$ Oznaczenia Ms i Ts odnoszą się do rękopisów (Ms) i maszynopisów (Ts) Wittgensteina według klasyfikacji G. H. von Wrighta (von Wright 1982: 35-63). 
Podobne sformułowania znajdujemy w jego Thesen napisanych pod koniec 1930 r. albo na początku 1931 r., które były próbą interpretacji głównych twierdzeń Traktatu logiczno-filozoficznego w świetle nowych idei powstałych w Kole. Waismann stwierdzał w nich między innymi:

Rozumieć zdanie oznacza wiedzieć, jak się rzeczy mają, kiedy zdanie jest prawdziwe.

[...].

Zdanie nie może mówić więcej niż to, co ustalone dzięki metodzie weryfikacji [...].

Sensem zdania jest sposób jego weryfikacji [...].

Zdanie ma sens nie dlatego, że jest poprawnie zbudowane, ale dlatego, że można je zweryfikować. Każde weryfikowalne zdanie jest zatem skonstruowane poprawnie. Jeśli podam metodę weryfikacji, to określę $\mathrm{w}$ ten sposób formę zdania, znaczenie słów, z których się składa, reguły składni itd. (Waismann 1984b: 244, 245).

Waismann nie mógł wprost powołać się na Traktat, ponieważ nie ma w nim mowy o weryfikacji. Weryfikacja pojawia się dopiero w rozmowie Waismanna z Wittgensteinem w grudniu 1929 r. Mógł jednak, tak jak inni koledzy z Koła, widzieć $\mathrm{w}$ swych słowach rozwinięcie myśli implicite zawartych w Traktacie. Waismann niemal dosłownie przepisał z niego fragment tezy 4.024: „Rozumieć zdanie, znaczy wiedzieć, co jest faktem, gdy jest prawdziwe” i połączył z weryfikacją: rozumieć zdanie, to wiedzieć, jak się je weryfikuje. Oba sformułowania wydają się mówić to samo. Takie odczytanie zakładało pewną ogólną interpretację tego, co za Peterem M. S. Hackerem moglibyśmy nazwać „doktryną izomorfizmu" (por. Hacker 1981: 89), zgodnie z którą język i rzeczywistość mają tę samą formę logiczną. Nazwy reprezentują proste przedmioty, a zdania są opisami stanów rzeczy, które są z kolei przedmiotami możliwego doświadczenia. W rozumieniu członków Koła nazwa jest połączona z przedmiotem za pomocą definicji ostensywnych, natomiast zdanie, będące według Wittgensteina ,jak miara przyłożona do rzeczywistości” (TLP 2.1512), za pomocą weryfikacji. To znaczy, że aby zrozumieć zdanie, musimy wiedzieć, co jest faktem, jeśli jest prawdziwe, czyli jakie doświadczenie je weryfikuje. Można to również interpretować jako pochodną z ducha Frege'owskiej tezy Wittgensteina o dwubiegunowości zdania: zdanie ma sens, kiedy może być prawdziwe albo fałszywe, ponieważ wiedzieć, kiedy może być prawdziwe albo fałszywe, to wiedzieć, co je weryfikuje.

Mając to na uwadze, moglibyśmy przyjąć, jak robi to na przykład Hacker (1996: 53), że w Traktacie widać pewne przyzwolenie na uznawanie weryfikowalności za kryterium empirycznego sensu zdań elementarnych, choć nie ma w nim definicji sensu zdania jako metody weryfikacji ${ }^{2}$. Według Michaela Wrigleya (1989: 284) Schlick i jego współpracownicy znaleźli w Traktacie przenikliwe ujęcie podstawowych założeń stanowiska, które sami wypraco-

\footnotetext{
2 Podobny pogląd głoszą Hans-Johann Glock (2001: 261) i Michael Hymers (2005: 210).
} 
wali niezależnie. Pamiętajmy, że między ukończeniem Traktatu a pierwszym spotkaniem z Kołem Wiedeńskim w 1927 r. poglądy Wittgensteina nie zmieniły się zasadniczo. Interpretacja Koła Wiedeńskiego nie mogła być bardzo odległa od intencji autora dzieła, w innym wypadku nie miałby on żadnego interesu - ani prawdopodobnie chęci - by kontynuować spotkania z ludźmi, którzy zupełnie nie rozumieli jego idei. Według Wrigleya Wittgenstein dostrzegał w dyskursie o weryfikacji, zdaniach protokolarnych, danych zmysłowych, fizykalizmie itp. wyraz sposobu myślenia pokrewnego z własnym. Być może dał się nawet przekonać co do tego, że kwestii sensu i znaczenia nie da się wyjaśnić z pominięciem kontekstu epistemologicznego. Źródłem weryfikacjonizmu był zatem, zdaniem Wrigleya, sam Traktat, w którym weryfikacjonizm zawarty jest implicite. $\mathrm{W}$ latach trzydziestych natomiast głoszony jest już przez Wittgensteina explicite.

\subsection{SYSTEM ZDANIOWY}

W literaturze przedmiotu istnieją też interpretacje, które sugerują, że krótki okres weryfikacji z 1929 i 1930 r. był raczej rezultatem wewnętrznej dynamiki rozwoju stanowiska Wittgensteina. Na przykład przywoływany już Hacker (1986: 139), który zasadniczo dopuszczał weryfikacjonistyczną wykładnię Traktatu w wydaniu przedstawicieli Koła Wiedeńskiego, twierdzi zarazem, że Wittgenstein takiej wykładni nie zaakceptował i że jego droga do weryfikacjonizmu z 1929 r. jest inna. Wiedzie przez uświadomienie sobie trudności, które napotyka Traktat w związku z problemem wykluczania się tak zwanych zdań o kolorach i niemożliwości utrzymania tezy o niezależności zdań elementarnych. W rezultacie Wittgenstein zaczyna mówić o systemie zdaniowym (Satzsystem) jako podstawowej jednostce sensu, ponieważ okazało się, że sens niektórych zdań zależny jest od innych zdań, a nie od samych ich właściwości logicznych, takich jak dwubiegunowość.

Wraz z upadkiem tezy o niezależności zdań elementarnych destrukcji ulega także ontologia Traktatu oraz cała doktryna izomorfizmu między językiem a światem. Świat nie składa się już z faktów, a fakty nie składają się z przedmiotów, które są znaczeniami nazw. Podobnie zdanie nie jest opisem możliwego stanu rzeczy. Na przykład wskazania na przedmiot w definicji ostensywnej koloru („To jest czerwone”) nie należy już postrzegać, jak robili to Waismann czy Schlick, jako połączenia słowa i rzeczy, lecz jako wzór należący do metody reprezentacji. To, czy dany przedmiot jest wzorem (koloru czerwonego), czy jest jako czerwony opisywany, nie jest funkcją wewnętrznych (logicznych) cech wyrażenia „to jest czerwone”, lecz zależy od sposobu jego użycia. Innymi słowy, wraz z porzuceniem traktatowej idei niezależności zdań 
elementarnych oraz pojawieniem się koncepcji systemu zdaniowego, nastąpiła zmiana sposobu aktualizacji sensu zdania, czyli porównywania go z rzeczywistością. Żeby wiedzieć, jaki sens ma zdanie, trzeba je odnieść do innych zdań, co oznacza między innymi: wiedzieć, jak się to zdanie weryfikuje, czyli ustala, czy zdanie (np. „To jest czerwone”) stosuje się jako wzór, czy jako opis. Według Hackera w 1929 r. zainteresowania Witttgensteina przesunęły się więc nie tylko ku systemowi zdaniowemu, lecz także w stronę metody porównania zdania z rzeczywistością3.

Podobnie Stuart Shanker (2006: 40-42) twierdzi, że w historii dyskusji na temat weryfikacji ważnym punktem jest powstanie koncepcji systemu zdaniowego. Według niego Wittgenstein, $\mathrm{w}$ przeciwieństwie do przedstawicieli Koła Wiedeńskiego, nie był zainteresowany weryfikacją jako środkiem ograniczającym wiedzę do doświadczenia zmysłowego, a tym samym jako kryterium demarkacji nauki i nienauki. Jeśli nawet źródła Wittgensteinowskiej zasady weryfikacji sięgają jego „pozytywistycznego intermedium” (Shanker 2006: 42), to jej stosowanie służyło wyłącznie wydobyciu technik używanych w celu wyjaśnienia logicznej składni zdania. Wraz z pojawieniem się koncepcji systemu zdaniowego Wittgenstein zaczą podkreślać różnorodność form zdaniowych. W nowej perspektywie Satzsystem to, czy dane zdanie jest sensowne, określają reguły składni logicznej, czyli systemu zdaniowego. Ale co, jeśli zdanie nie należy do żadnego z tych systemów? Albo inaczej: czy w ogóle sensowne jest mówienie o zdaniach nienależących do żadnego systemu? Klucz do odpowiedzi Wittgensteina tkwił w specyficznej roli, którą odgrywa zasada weryfikacji (por. Shanker 2006: 41). Dla Wittgensteina to, że sens zdania dany jest na mocy metody jego weryfikacji, oznacza, że pokazuje ona, do którego systemu zdaniowego należy to zdanie. Według Shankera metodę weryfikacji jako ustalania sensu zdania zastosował on następnie w Philosophische Bemerkungen do filozofii matematyki.

\subsection{INTUICJONIZM BROUWERA}

W rozważaniach o genezie Wittgensteinowskiego weryfikacjonizmu z $1929 \mathrm{r}$. nie można także pominąć interpretacji nawiązującej do idei Michaela Dummetta (1978: 379), który wpisuje pojęcie weryfikacji we współczesny spór między realizmem a antyrealizmem. Według niego weryfikacjonistyczna teoria znaczenia, wbrew poglądom filozofów Koła Wiedeńskiego, radykalnie różni się od wyrażanego explicite $\mathrm{w}$ Traktacie ujęcia znaczenia $\mathrm{w}$ terminach warunków prawdziwo-

\footnotetext{
${ }^{3}$ Stanowisko to Wittgenstein prezentował także w wykładach z początku lat 30. (por. Wittgenstein 1980: 66).
} 
ści. Zgodnie z Traktatem znać znaczenie zdania, to wiedzieć, w jakich warunkach jest ono prawdziwe. Weryfikacjonizm przyjmuje natomiast, że znamy znaczenie zdania, kiedy jesteśmy w stanie rozpoznać to zdanie jako ostatecznie zweryfikowane albo sfalsyfikowane. W antyrealistycznej semantyce znaczenie ujmowane $\mathrm{w}$ terminach warunków prawdziwości zastępuje się rozumieniem znaczenia $\mathrm{w}$ terminach warunków uzasadnionej stwierdzalności ${ }^{4}$. W przypadku Wittgensteina droga do takiego stanowiska wiodła przez intuicjonizm Brouwera. Jak wiadomo, Wittgenstein wysłuchał w Wiedniu w marcu $1928 \mathrm{r}$. wykładu Brouwera Mathematik, Wissenschaft und Sprache i był nim, zgodnie ze świadectwem Feigla, bardzo podekscytowany. Oczywiście metafizyka intuicjonizmu Brouwera, a ściśle mówiąc jego psychologizm, mogła dość skutecznie zniechęcać Wittgensteina i jego gwaltowna reakcja oraz ożywione dyskusje po wykładzie, o których wspomina Feigl, prawdopodobnie były wywołane raczej sprzeciwem niż zgodą. Jeśli jednak spojrzymy na stanowisko Brouwera tak, jak zrobił to Dummett, to możemy uznać psychologizm za irrelewantny, a nawet sprzeczny $\mathrm{z}$ istotą intuicjonizmu matematycznego. Zgodnie z interpretacją Dummetta intuicjonizm głosi bowiem, że zamiast definiować znaczenie zdań matematycznych $\mathrm{w}$ odniesieniu do warunków ich prawdziwości, musimy przyjąć, że znaczenie określone jest przez warunki dowodu (proof-conditions) (por. Wrigley 1989: 275). Wittgenstein podobnie odczytałby intencje Brouwera, dostrzegając możliwość oddzielenia intuicjonistycznej semantyki od jej psychologistycznego tła. Wystarczyło teraz zastosować koncepcję znaczenia odwołującą się do warunków dowodu nie tylko do zdań matematycznych, lecz także do wszystkich zdań, by otrzymać koncepcję znaczenia odwołującą się do warunków weryfikacji. W tym nowym ujęciu rozumieć zdanie, to wiedzieć, jak się je weryfikuje.

Choć przedstawiona interpretacja drogi Wittgensteina do weryfikacjonizmu jest dopuszczalna, to istnieją pewne argumenty, które czynią ją problematyczną. Istotą interpretacji Dummetta było twierdzenie, że intuicjonizm Brouwera dostarczył Wittgensteinowi modelu dla nowego ujęcia znaczenia zdań matematycznych. Weryfikacjonizm byłby wynikiem generalizacji tego nowego ujęcia i zastosowania go do całego języka. Obie tezy są jednak, zdaniem Wrigleya, błędne (por. Wrigley 1989: 277-280). Mimo pewnych podobieństw między intuicjonizmem a poglądami Wittgensteina na podstawy matematyki z przełomu lat 1929-1930 koncepcje te też się istotnie różniły. Intuicjonizm zakładał bowiem, podobnie jak inne stanowiska metamatematyczne z tego okresu, że zdania matematyczne opisują pewną dziedzinę fak-

\footnotetext{
4 Interpretację weryfikacjonizmu Wittgensteina jako dowodu jego przejścia od realizmu do antyrealizmu przedstawił m.in. Crispin Wright (1980: rozdz. X-XI). Omówienia i krytyki takiego ujęcia podjął się Shanker (2006: 42-59).
} 
tów, mają zatem treść opisową, są o czymś. Tymczasem podstawową intuicją Wittgensteina było przekonanie, że zdania matematyczne nie zawierają treści deskryptywnej, lecz preskryptywną, czyli normatywną. W Big Typescript (1933) pisał na przykład:

Jeśli mówimy o sensie zdań matematycznych, albo o tym, czego one dotyczą, to odwołujemy się do fałszywego obrazu. Mianowicie jest tutaj tak, jak gdyby nieistotne, arbitralne znaki zawierały to, co istotne, czyli sens. Ponieważ matematyka jest pewnym rachunkiem i dlatego z istoty o niczym nie traktuje, żadna metamatematyka nie istnieje (BT: 358$)^{5}$.

Wittgenstein odrzucał pogląd, że zdania matematyczne mają sens, który wymagałby eksplikacji i który mógłby być zastosowany do całego języka. Dlatego byłoby błędem dopatrywanie się źródeł Wittgensteinowskiego weryfikacjonizmu w zastosowaniu modelu znaczenia odwołującego się do dowodu nie tylko do zdań matematycznych, lecz także do reszty języka. Po prostu nie ma czego uogólniać i rozciągać na cały język. Mimo że wpływ Brouwera na Wittgensteina $\mathrm{w}$ wielu innych kwestiach, na przykład w kwestii matematycznej nieskończoności, jest trudny do pominięcia, to źródeł weryfikacjonizmu autora Traktatu nie należy doszukiwać się w teorii twórcy matematycznego intuicjonizmu.

\section{WERYFIKACJONIZM WITTGENSTEINA W NOTATACH 1929-1931 I W ROZMOWACH ZE SCHLICKIEM I WAISMANNEM}

\subsection{FENOMENOLOGIA}

Spróbuję przedstawić własną interpretację Wittgensteinowskiego weryfikacjonizmu - zarówno jego sensu, jak i genezy - wychodząc od analizy uwag Wittgensteina z lat 1929-1931 oraz rozmów ze Schlickiem i jego współpracownikami. Po raz pierwszy pojęcia weryfikacji użył Wittgenstein w uwagach pochodzących z początku 1929 r. w kontekście rozważań dotyczących matematyki. Weryfikację utożsamiał wtedy z dowodem matematycznym. Pod koniec 1929 r. napisał na przykład: „Każde zdanie jest instrukcją swojej weryfikacji” (Ms 106: 16), skreślając słowo „dowód” i wpisując „weryfikację”. Kilka stron dalej czytamy:

Jaka jest czysto techniczna weryfikacja

$(\mathrm{x}): \mathrm{x}^{2}=2 \mathrm{x} \supset \mathrm{x}=0 \vee \mathrm{x}=2$

Obliczam x z równania, wstawiam wszędzie wartość, a następnie muszę otrzymać zdanie prawdziwe.

5 Dalej skrótem BT będziemy oznaczać The Big Typescript (Wittgenstein 2000a). 
$[\ldots]$

Czym jednak jest weryfikacja $(\exists x) \mathrm{x}^{2}=2 \mathrm{x}$ ? Mam na myśli konkretną weryfikację tego zdania, w przeciwieństwie do weryfikacji , $(\mathrm{x}): \mathrm{x}^{2}=2 \mathrm{x} \vee \mathrm{x}=0$ ”. Czy inne zdanie (tzn. inny sens) nie musi być inaczej weryfikowane? Na przykład zdanie ogólne - ogólniej (Ms 106: 40-42).

Z tych i im podobnych fragmentów mogłoby wynikać, że Wittgenstein nie używał pierwotnie terminu „weryfikacja” w sensie empirycznym, na przykład w sensie odwołania do bezpośredniego doświadczenia zmysłowego. Jak zobaczymy, takie ujęcie byłoby jednak błędne. Moim zdaniem problem weryfikacji należy łączyć bezpośrednio z projektem fenomenologii i tak zwanego języka pierwotnego (primäre Sprache), który Wittgenstein rozwijał zaraz po powrocie do Cambridge w lutym 1929 r. Projekt ten zainspirowany był dyskusjami prowadzonymi na seminariach Schlicka, gdzie omawiano między innymi kwestię stosunku konstrukcji matematycznych w postaci danej teorii fizycznej do danych zmysłowych. Schlick i inni przedstawiciele Koła Wiedeńskiego podążali w tym względzie za Ernstem Machem, który reprezentował fenomenologiczne podejście do fizyki ${ }^{6}$. W jego przekonaniu nasze zmysły są jedynym źródłem prawomocnego opisu zjawisk fizycznych, a wszystkie terminy abstrakcyjne powinny być zredukowane do doświadczenia zmysłowego. Wittgenstein był jednak uważnym czytelnikiem Die Prinzipien der Mechanik Heinricha Hertza i w jego duchu ujmował relację między empirycznymi i apriorycznymi elementami teorii. Hertz wyraźnie odróżniał wewnętrzną strukturę modeli matematycznych zjawisk mechanicznych od tego, jakie zastosowanie znajdują one w doświadczeniu, to znaczy, na ile i jak dalece można je wykorzystać do opisu świata danego nam w codziennym doświadczeniu. Według Macha dane zmysłowe (scil. wrażenia) wyznaczały zewnętrzną granicę danej teorii fizycznej. To, czego nie można było sprowadzić do języka wrażeń (języka fenomenologicznego), nie nadawało się do opisu świata empirycznego. Zdaniem Hertza granice teorii były natomiast granicami wewnętrznymi, to znaczy teoria jako zbiór możliwości wyznaczała nieprzekraczalne granice, w których zachodzić mogły zjawiska i procesy fizyczne. Idąc śladami Hertza (i Boltzmanna), Wittgenstein twierdzil, że żaden system formalnych praw, rozumiany jako system możliwości w „przestrzeni logicznej”, „sposób przedstawiania”, „symbolizm” albo po prostu ,język", nie może być na mocy własnych reguł zamieniony w empiryczny opis świata (por. TLP 6.342). Przedstawiciele Koła Wiedeńskiego nie widzieli jednak żadnej zasadniczej niezgodności między programem Macha a filozofią Traktatu. W ich ujęciu dzieło Wittgensteina dostarczało, opierając się na symbolizmie Principia Mathematica, logicznych podstaw, głównie w postaci teorii logicznego atomizmu, pozytywistycznej teorii wiedzy. Filozo-

${ }^{6}$ Por. na ten temat (Janik, Toulmin 1973: 212-218). 
fia Macha wypełniała natomiast formalny szkielet empiryzmu treścią przez zrównanie „faktów atomowych” z wrażeniami. „Zdania elementarne” z Traktatu stają się $\mathrm{w}$ konsekwencji zdaniami protokolarnymi połączonymi ostensywnie z treścią naszych doznań zmysłowych. Wydaje się, że Wittgensteinowski język fenomenologiczny, czyli język pierwotny, może być - przynajmniej częściowo - rozumiany jako próba zajęcia stanowiska w sprawie bezpośredniego, tj. odnoszącego się do wrażeń zmysłowych, opisu zjawisk.

Śledząc notatki Wittgensteina $\mathrm{z}$ tego okresu, możemy najogólniej powiedzieć, że jego fenomenologia wiązała się z widzeniem, postrzeganiem i przestrzenią wizualną (Gesichtsraum). Wittgenstein próbowal określić istotę fenomenologii, porównując ją z fizyką:

Fizyka dąży do prawdy, to znaczy do trafnych przewidywań, podczas gdy fenomenologia tego nie robi; kieruje się ona na sens, nie na prawdę. [...]

Istnieje określona różnorodność sensu i inna różnorodność praw. Fizyka różni się od fenomenologii tym, że chce formułować prawa. Fenomenologia ustala tylko możliwości.

Fenomenologia byłaby więc gramatyką opisu tego rodzaju faktów, na których fizyka buduje swoje teorie (Ms 105: 1-9).

Zestawienie fizyki i fenomenologii mogłoby sugerować, że ta druga dotyczy bardziej podstawowego poziomu opisu zjawisk, to znaczy obszaru bezpośredniego doświadczenia, i w tym sensie stanowi fundament fizyki. Inaczej jednak niż w fenomenologii Macha, Wittgensteinowi nie chodziło o redukcję abstrakcyjnych terminów teorii fizycznej do danych zmysłowych w postaci wrażeń. Nie było także jego celem ugruntowanie całego naszego poznania świata na bezpośrednim doświadczeniu. Nie wydaje się, by mówiąc o sensie, do którego dąży fenomenologia, i prawdzie będącej celem fizyki, Wittgenstein chciał z tej pierwszej uczynić coś w rodzaju hermeneutyki objaśniającej sens fizycznych pojęć i terminów podstawowych w odwołaniu do języka danych zmysłowych. Pamiętając o tym, jak rozumiał sens zdania w Traktacie, moglibyśmy przyjąć, że fenomenologia formułuje zdania dotyczące treści naszych wrażeń zmysłowych, które mogą być prawdziwe albo fałszywe, a tym samym wyznacza obszar możliwości. Jest więc tożsama ze składnią albo gramatyką, a nie z opisem bezpośredniego doświadczenia, które byłoby samooczywiste i źródłowo prawdziwe. W zamyśle Wittgensteina język fenomenologiczny jako język pierwotny (primäre Sprache) miał różnić się od języka potocznego, fizycznego, czyli języka wtórnego (sekundäre Sprache), tym, że opisywał nasze bezpośrednie doświadczenie zmysłowe, był formowany przez same zjawiska i w tym sensie weryfikowalny:

Język fenomenologiczny opisuje dokładnie to samo, co język potoczny, fizykalny. Musi się jednak ograniczyć do tego, co weryfikowalne (Ms 106, 108). 
Taki język pozwalałby unikać sprzeczności i dwuznaczności języka potocznego, który stał się złożoną strukturą zasłaniającą dostęp do rzeczy samych, między innymi przez użycie w nim kategorii i pojęć naukowych. Język fenomenologiczny powinien nie tyle umożliwiać dostęp do zjawisk, ile być raczej adekwatnym odzwierciedleniem ich logicznej struktury, ponieważ sam pomyślany jest jako logicznie poprawny, a jego gramatyka jako całkowicie odpowiadająca składni logicznej.

Wittgensteina niepokoiła w tym czasie podniesiona w recenzji Traktatu Franka Ramseya kwestia, która jak się okaże, miała istotne znaczenie dla jego rozumienia weryfikacji. Związana była z podjętym w środku okresu fenomenologicznego w artykule Kilka uwag o formie logicznej7 problemie wykluczania się zdań o kolorach. Chodziło o to, że jeśli sprzecznością jest zdanie „A jest czerwone i A jest niebieskie”, to oba człony tej koniunkcji, czyli zdania „A jest czerwone” oraz „A jest niebieskie”, nie mogą być zdaniami elementarnymi, ponieważ zdania te są w myśl Traktatu od siebie niezależne, a koniunkcja dwóch zdań elementarnych nie może być sprzecznością. Taka konkluzja jest jednak bardzo kłopotliwa, ponieważ nie jest jasne, jakie zdania inne niż te o formie logicznej „A jest x” mogłyby być w takim razie zdaniami elementarnymi. Jeśli uświadomimy sobie, że podobny problem odnosi się do wszystkich innych zdań elementarnych przypisujących specyficzne własności danemu przedmiotowi, to trudno sobie wyobrazić, jak przypisanie takich cech jest do pogodzenia z przypisaniem mu innych cech - w tym samym miejscu i czasie. Problem był więc bardzo poważny. Można go rozwiązać na dwa sposoby: albo uznamy, że zdania typu „A jest czerwone” nie są zdaniami elementarnymi, a więc dają się rozłożyć na jeszcze prostsze zdania spełniające warunek logicznej niezależności, a nazwy „czerwony”, „niebieski” nie są nazwami prostych przedmiotów (przyjmując, że są to przedmioty), albo odrzucimy całą koncepcję niezależności zdań elementarnych i wraz z nią zasadę ekstensjonalności, czyli koncepcje dla Traktatu fundamentalne.

Początkowo Wittgenstein dostrzegał pierwszą możliwość, uznał ją jednak niewykluczone, że pod wpływem Ramseya - za błędną. Nie oznacza to jednak, że pozostawało jedynie drugie wyjście, negujące główne idee Traktatu i dlatego trudne do zaakceptowania. W Uwagach o formie logicznej Wittgenstein przedstawił inny argument, który wiązał się z modyfikacją reguł składni logicznej rządzących spójnikami logicznymi. Zgodnie z nim zdania elementarne nie mogą być wprawdzie sprzeczne ze sobą, ale mogą się wzajemnie wykluczać. Zdanie „A jest czerwone” nie jest sprzeczne z „A jest zielone”, ale się wykluczają, to znaczy oba zdania chcą przypisać przedmiotowi kolor czerwony i zielony

7 O problemie tym pisałem szczegółowo w (Dehnel 2014: 270-282). 
w jednym miejscu i czasie, podczas gdy „jest miejsce” tylko na jeden kolor. Funkcja mówiąca o istnieniu w jednym miejscu i czasie zostawia miejsce tylko dla jednego przedmiotu. To wykluczanie się kolorów istnieje na poziomie zdań elementarnych i nie daje się niestety wyeliminować przez analizę logiczną. Oznaczało to zarazem, że reguł składni logicznej nie można wywieść z analizy zdań języka potocznego. Reguły te powinny być tak określone, aby uniemożliwiały tego rodzaju trudności przez wyeliminowanie pewnych konstrukcji $P$ i $F$, co powinno się dokonać w ostatecznej analizie fenomenologicznej, a więc poniekąd a posteriori. Choć Wittgenstein nie używa w tekście Uwag pojęcia języka fenomenologicznego, to o taki język właśnie mu chodziło - język wolny od wskazanych wyżej trudności wykluczania się kolorów. W takim języku nie będzie miejsca dla konstrukcji typu „A jest czerwone i A jest zielone”, ponieważ nie dopuści do tego składnia języka fenomenologicznego, podobnie jak na pytanie: „Jaka jest temperatura na zewnątrz?”, składnia ta wyklucza odpowiedź: „Jest $23^{\circ} \mathrm{C}$, ale nie jest $25^{\circ} \mathrm{C}$ ”, a zapytani: „Która jest godzina?” - nie odpowiadamy, podkreślając dodatkowo, której godziny nie ma (Wittgenstein 1997b: 154).

Analiza fenomenologiczna powinna uświadomić nam, że struktury zdań elementarnych nie można z góry przewidzieć, choć do takiego poglądu mógłby skłaniać język potoczny ze swymi formami podmiotowo-orzecznikowymi i relacyjnymi. Z faktu istnienia takich form nie możemy wyciągać wniosków o rzeczywistej logicznej formie opisywanych faktów. Zdania takie jak „Ta książka jest nudna”, „Bóg istnieje”, „Jutro będzie padać”, „2+2=4” itp. nie mają ze sobą nic wspólnego, choć są zdaniami podmiotowo-orzecznikowymi, a więc pozornie zdaniami o tej samej formie. W rzeczywistości w nasz język „rzutujemy na tak wiele różnych sposobów tak wiele różnych form logicznych" (Wittgenstein 1997b: 152). Adekwatny opis tych form wymaga raczej logicznej analizy samych zjawisk, to znaczy języka fenomenologicznego, pierwotnego, a nie analizy form języka potocznego, wtórnego.

W Uwagach o formie logicznej Wittgenstein podtrzymywał wyrażony w Traktacie pogląd o możliwości adekwatnej reprezentacji rzeczywistości, ale zmieniała się droga, na której można to osiągnąć. Logiczna struktura rzeczywistości nie jest rekonstruowana na podstawie badań apriorycznych, lecz w odwołaniu do bezpośredniego doświadczenia, w relacji do samych zjawisk, opisywanych w języku fenomenologicznym. W tej analizie na pierwszy plan wysuwa się treść zdań oraz fakt, że skoro okazało się, że wartości logiczne jednych zdań mogą wyznaczać wartości innych zdań bądź też, co wychodzi na jedno, zależą od treści zdania, to oznacza, że zdania elementarne należą raczej do pewnego systemu zdaniowego, który porównywany jest z rzeczywistością 
jako całość8. System zdaniowy tworzy się zatem za sprawą relacji inferencyjnych. Innymi słowy, zdania w system łączą wewnętrzne relacje między zdaniami. Co ważne jednak, nie są to już relacje formalne, lecz materialne, to znaczy opierają się na treści zdań. Ten inferencjalistyczny pogląd średniego Wittgensteina byl zdecydowanym odejściem od formalizmu Traktatu (por. Medina 2002: 42). Okazało się, że logika nie jest w stanie wyrazić symbolicznie wszystkich rzeczywistych sposobów użycia języka. Dlatego też jego funkcjonowanie zaczyna Wittgenstein wyjaśniać w tym okresie, nie opierając się na jego strukturze logicznej, lecz na relacjach inferencyjnych. Miało to poważne konsekwencje dla pojmowania sensu zdania. Otóż nie jest on już utożsamiany z formalną dwubiegunowością zdania, ale z jego przynależnością do określonego systemu zdaniowego, która uzależniona jest od treści, a nie formy zdania. Celowi ustalania treści zdania, tego, co ono mówi, a tym samym klasyfikacji do określonego systemu zdaniowego, miała służyć weryfikacja.

\subsection{WERYFIKACJA W ROZMOWACH ZE SCHLICKIEM I WAISMANNEM}

Od końca 1929 r. Wittgenstein zaczyna częściej odwoływać się do metody weryfikacji. Jej właściwy sens starał się wyjaśnić między innymi w rozmowach ze Schlickiem. W jednej z nich stwierdzil: „Aby ustalić sens zdania, muszę znać ściśle określoną metodę, kiedy zdanie powinno być uznane za zweryfikowane” (WWK 47)9. Jeśli mówimy na przykład: „Tam na górze na szafie leży książka", to kiedy mogę uznać takie zdanie za zweryfikowane? Czy wtedy, gdy dostrzegę książkę na szafie? Czy kiedy obejrzę ją z różnych stron? A może wtedy, kiedy wezmę ją do ręki i przekartkuję? Są tu dwie możliwe interpretacje: zgodnie $\mathrm{z}$ pierwszą taka weryfikacja $\mathrm{w}$ istocie nigdy nie miałaby końca,

\footnotetext{
824 grudnia 1929 r., a więc niedługo po napisaniu Kilku uwag o formie logicznej, Wittgenstein zapisał w swoim dzienniku: „Nowe ujęcie »zdań elementarnych« mówi, że zdanie może być bardziej bądź mniej blisko prawdy. (Ponieważ czerwień jest bliżej pomarańczowego niż niebieskiego, a $2 \mathrm{~m}$ bliżej $201 \mathrm{~cm}$ niż $3 \mathrm{~m}$.). W tym przypadku zdania stają się jeszcze bardziej podobne do miar niż wcześniej sądziłem. - Zgodność jednej miary wyklucza automatycznie wszystkie inne. Ja za to mówię automatycznie: tak, jak wszystkie kreski podziałki znajdują się na jednej linijce, tak zdania, które odpowiadają kreskom podziałki, tworzą całość i nie można mierzyć jednym z nich, nie mierząc zarazem wszystkimi innymi. - Do rzeczywistości nie przykładam zdania jako miary, ale system zdań (System von Sätzen)" (Ms 108: 35).

9 WWK = (Waismann 1984b). Nieco wcześniej zanotował w Dzienniku: „To zdanie mówi, jak się je weryfikuje. Porównajmy ogólność zdań właściwych (eigentliche Sätze) z ogólnością w arytmetyce. Jest ona weryfikowana inaczej i dlatego jest inną ogólnością. Weryfikacja nie jest instrukcją prawdziwości, ale sensu zdania” (Ms 107: 143). Dalej pisał też: „Każde zdanie jest swobodną grą kresek i dźwięków bez związku z rzeczywistością, a [jego] jedynym związkiem z rzeczywistością jest sposób jego weryfikacji” (Ms 107: 177).
} 
cokolwiek byśmy tu uczynili, to nigdy nie możemy być pewni, że się nie mylimy. Zgodnie z drugim ujęciem, które popiera Wittgenstein, jeśli nigdy nie możemy w pełni zweryfikować jakiegoś zdania, to znaczy, że wypowiadając je, niczego nie mieliśmy na myśli, a wtedy zdanie to zupełnie nic nie znaczy. „Aby ustalić sens zdania, musiałbym znać wyraźnie określoną metodę, kiedy zdanie ma być uznane za zweryfikowane" (WWK 47). Tutaj jednak język potoczny okazuje swą słabość, o wiele większą niż język nauki, ponieważ w języku potocznym symbole nie dają się jednoznacznie zdefiniować, a słowa oscylują między rozmaitymi znaczeniami. Dlatego nie jest pewne, kiedy jakieś zdanie jest w pełni zweryfikowane, a więc jaki ma ostatecznie sens. Wittgenstein podaje przykład zdania, którego weryfikacja jest bardzo trudna: „Seitz został wybrany na burmistrza"10. Jak zweryfikować takie zdanie? Czy przez obserwację tego wydarzenia? Czy pytając innych, którzy byli podczas wyboru? Ale których, tych z przodu, czy tych z tyłu? A może należałoby przeczytać gazetę?

Zdaniem Wittgensteina $\mathrm{w}$ języku potocznym ciągle mamy do czynienia z różnicą między pozorem a rzeczywistością. Zdanie „To jest żółte” mogę weryfikować na rozmaite sposoby i w zależności od metody weryfikacji zdanie to będzie miało różny sens. Jeśli na przykład środkiem weryfikacji byłaby określona reakcja chemiczna, to ma sens powiedzenie: „To wygląda na szare, ale w rzeczywistości jest żółte" (WWK 97). Z kolei jeśli weryfikacją będzie to, co widzę, to powiedzenie „To wygląda na żółte, ale w rzeczywistości jest szare”, sensu nie ma. $W$ tym wypadku nie mogę już poszukiwać jakiejś oznaki tego, że to jest żółte, ponieważ jest to (moje widzenie tego) faktem. Moim widzeniem żółtego przedmiotu dotarłem do ostatecznego punktu, poza który dalej sięgnąć nie mogę. „W odniesieniu do tego, co dane bezpośrednio, nie mogę stawiać żadnych hipotez" (WWK 97).

Z kolei odwołując się do pojęcia czasu, Wittgenstein zauważa, że cała trudność dyskursu fizycznego na jego temat bierze się z pomieszania reguł gramatyki, a ściślej mówiąc, z podwójnego znaczenia słowa „czas”: jako wspomnienia i jako wielkości fizycznej. Te dwa znaczenia wynikają z różnych sposobów weryfikacji zdań zawierających określenia temporalne. Jeśli na przykład stwierdzam, że coś wydarzyło się wcześniej, to mogę zdanie to zweryfikować tylko przez odwołanie do pamięci. Wtedy „czas” będzie miał inne znaczenie niż w przypadku, gdy takie zdanie z użyciem słowa „czas” jest weryfikowane przez dokumenty czy wiedzę potwierdzoną przez innych. Czasami określa się wspomnienia jako obrazy przeszłości, ale taka metafora jest błędna - wspomnień nie mogę, tak jak obrazu, skonfrontować z rzeczywistością. Wspomnienia przeszłości nie istnieją przecież jak przedmioty w pokoju, któ-

${ }^{10}$ Karl Seitz był burmistrzem Wiednia w latach 1925-1934. 
rych teraz wprawdzie nie widzę, ale zawsze mogę wejść do pokoju i je zobaczyć. Do przeszłości wejść nie mogę. „Tam, gdzie istnieją różne weryfikacje, tam istnieją także różne znaczenia” (WWK 53).

Problem weryfikacji stał się ponownie tematem rozmowy ze Schlickiem w styczniu $1931 \mathrm{r}$. (por. WWK 158). Schlick dociekal, jak należy rozumieć twierdzenie, że sensem zdania jest metoda jego weryfikacji: czy można w ogóle powiedzieć, że jedno zdanie weryfikuje się na różne sposoby? Jego zdaniem to właśnie prawa przyrody są tym, co łączy różne sposoby weryfikacji. Pisał:

Możemy wziąć oto całkiem prosty przykład: mierzę pewną długość, raz przykładając do niej miarę, drugim razem za pomocą przyrządu optycznego. W zasadzie nie byłoby wcale konieczne, by oba rezultaty zgadzały się ze sobą. Jeśli już jednak tak by było, to ujawnia się w tym prawo przyrody (WWK 158).

Wittgenstein w odpowiedzi stwierdzil, że taka sytuacja ma miejsce nie tylko w nauce, lecz także w życiu codziennym:

Słyszę np. obok w pokoju grę na pianinie i mówię: „Tam w pokoju jest mój brat”. Jeśli ktoś zapytałby, skąd to wiem, to mógłbym odpowiedzieć: „Powiedział mi, że w tym czasie będzie w pokoju obok”. Albo: „Słyszę grę na pianinie i rozpoznaję w niej jego sztukę”. Albo: „Słyszałem przed chwilą kroki, które były zupełnie jak jego” itp. Wydaje się więc, że to samo zdanie zweryfikowałem za każdym razem na rozmaite sposoby. Ale tak nie jest. To, co zweryfikowałem, to są różne „symptomy” czegoś innego. [...] Gra na pianinie, kroki itp. to są symptomy obecności mojego brata (WWK 158-159).

Te i podobne wypowiedzi Wittgensteina wskazują, że nie chodziło mu o nową koncepcję znaczenia, lecz o problem różnego użycia wyrażeń językowych. Rozmaite sposoby weryfikacji zdania służą do zaliczenia go do jednego z systemów zdaniowych.

W czasie, o którym mówimy, Wittgenstein wyróżniał trzy główne systemy zdaniowe, czyli trzy rodzaje zdań: zadania właściwe (eigentliche Sätze) albo pierwotne (primäre Sätze) (por. BT 88), to znaczy zdania, które mogą być efektywnie zweryfikowane bądź sfalsyfikowane przez porównanie z rzeczywistością, ponieważ wyrażają treści doświadczenia zmysłowego. Odpowiadałyby one zdaniom tak zwanego języka fenomenologicznego opisującego to, co bezpośrednio dane, jakkolwiek samą możliwość takiego języka Wittgenstein już wówczas odrzucał. Drugim rodzajem zdań są hipotezy, rozumiane przez niego dość szeroko i, przyznajmy, nie zawsze jasno opisywane. Oprócz hipotez naukowych, takich jak hipotezy fizyki, do hipotez zaliczał też zdania języka potocznego:

Każde zdanie, które wypowiadamy w języku potocznym, wydaje się mieć charakter hipotezy (Ms 108: 249). 
Najogólniej rzecz ujmując, hipotezy to zdania niedające się definitywnie zweryfikować w doświadczeniu:

Hipotezą nazywam każde zdanie, które nie poddaje się definitywnej weryfikacji. Jeśli dana hipoteza nie może być definitywnie zweryfikowana, to w ogóle nie może być zweryfikowana, a wtedy prawda i fałsz dla niej nie istnieją (Ms 108: 284).

Jeden z rozdziałów The Big Typescript nosi tytuł Istota hipotezy i składa się $\mathrm{z}$ wybranych przez Wittgensteina fragmentów rękopisu Ms 108. Co ciekawe, pominął w nim te fragmenty rękopisu, które wprost definiowały hipotezę przez odniesienie do weryfikacji. Jak się okaże, nie było to przypadkowe. W BT Wittgenstein twierdzil, że

hipoteza jest prawem tworzenia zdań. Można by nawet powiedzieć: jest prawem tworzenia oczekiwań. Zdanie jest poniekąd przekrojem hipotezy w określonym miejscu (BT 87).

Sformułowanie to nawiązuje do rozmów ze Schlickiem na temat weryfikacji zdań fizyki. W jednej z takich rozmów Wittgenstein stwierdzil, że równania fizyki nie są zdaniami, ale właśnie hipotezami. Tymczasem to, co obserwujemy, to tylko pojedyncze wycinki czy też przekroje hipotez („die Schnitte durch die Hypothesen"), dokonane nie tylko w określonym miejscu i czasie, lecz mające także określoną formę logiczną. Te wycinki są zatem w rzeczywistości różnymi faktami. Jedyne, co możemy zweryfikować, to taki właśnie jeden wycinek, fragment czy też strona danej hipotezy, którą w tym sensie możemy porównać do trójwymiarowej bryły rzutowanej na rozmaite sposoby. Według Wittgensteina hipoteza łączy w sobie wszystkie te różnorodne fragmenty, tak jak krzywa łączy różne punkty albo bryła różne sposoby rzutowania. Tak rozumiana hipoteza odnosi się nie tylko do równań fizyki, lecz także do zdań języka potocznego. Przykłady codziennych hipotez wskazane przez Wittgensteina to: „Tu leży książka”, „Mój brat jest w pokoju obok” itd. Możemy zdania te weryfikować po prostu na różne sposoby, które są właśnie owymi wycinkami, przekrojami, stronami albo aspektami, czasem określanymi przez Wittgensteina mianem „symptomów”.

Trzecim rodzajem zdań są zdania matematyczne. W matematyce weryfikacja oznacza metodę dowodu. W swoich notatkach Wittgenstein często zestawiał pojęcia weryfikacji i dowodu, a nawet używał ich zamiennie. Należy jednak pamiętać, że ta analogia jest zwodnicza i że Wittgenstein był daleki od utożsamienia dowodu z weryfikacją, co świadczyłoby o pewnym pokrewieństwie między zdaniami empirycznymi a matematycznymi. Podkreślał raczej różnice między nimi. Dowód matematyczny nie dowodzi bowiem prawdy o świecie przedmiotów matematycznych, lecz jest konstrukcją gramatyczną, pewną regułą reprezentacji. Pisał na przykład: 
Nic nie jest bardziej zgubne dla filozoficznego zrozumienia niż ujęcie dowodu i weryfikacji jako dwóch różnych, a więc porównywalnych metod weryfikacji (Ms 108: 295).

Przedstawiony podział zdań nie utrzymał się jednak długo. W latach 19321933 Wittgenstein doszedł do wniosku, że zdania właściwe, które odnosiły się do bezpośredniego doświadczenia zmysłowego i były efektywnie weryfikowalne, $\mathrm{w}$ istocie takimi nie są, a porównywanie ich z rzeczywistością nie ma sensu. Jak bowiem zrobić to w przypadku zdań typu: „boli mnie głowa” czy „widzę czerwone jabłko"? Równie szybko znikają ze słownika Wittgensteina pojęcia hipotezy i symptomu (por. Hacker 1996: 58).

\section{PODSUMOWANIE}

Śledząc wypowiedzi Wittgensteina na temat weryfikacji, możemy powiedzieć, że niemal od początku miała ona dla niego sens gramatyczny, to znaczy była sposobem ustalania sensu zdania. „Pytanie o weryfikację jest tylko inną postacią pytania »Co masz na myśli?«” (Ms 112: 97). Wittgenstein początkowo używał pojęcia weryfikacji w kontekście zdań matematycznych i utożsamiał ją z dowodem, co jednak - jak widzieliśmy - zostało zakwestionowane, kiedy zaczął dostrzegać wyraźne różnice w funkcjonowaniu języka i przekonał się o specyfice tych zdań.

Częściej jednak weryfikacja pojawiała się u Wittgensteina w kontekście fenomenologii oraz tak zwanego języka fenomenologicznego. Odnosi się wówczas do bezpośredniego doświadczenia. Wydaje się, że ten empiryczny sens weryfikacji mógł zostać podchwycony przez Wittgensteina w trakcie dyskusji z filozofami Koła Wiedeńskiego. Autor Traktatu spotykał się z członkami Koła na seminariach Schlicka od 1927 r. i jest wysoce prawdopodobne, że temat weryfikacji był tam dyskutowany. Pamiętajmy także, że w 1929 r. Wittgenstein pozostawał jeszcze wierny wielu tezom Traktatu (por. Engelmann 2013: 25-28). Choć nie używał w nim pojęcia weryfikacji, to na przykład w tezie 4.024 pisał, że „Rozumieć zdanie, znaczy wiedzieć, co jest faktem, gdy jest prawdziwe”. Powtórzył ją w zasadzie w jednej z notatek z 10.06.1929: „Moją główną myślą (Hauptgedanke) jest, że zdanie porównuje się z rzeczywistością" (Ms 107: 155). Teraz chodziło mu o to, w jaki sposób dokonuje się to porównanie, jeśli pamięta się o zasadzie określoności sensu, czyli o tym, że: „Rzeczywistość musi być przez zdanie ustalona na »tak « lub »nie«. Na to musi być przez nie opisana całkowicie" (TLP 4.023). Porównanie zdania z rzeczywistością Wittgenstein uzależnił od metody jego weryfikacji, co było istotną zmianą w porównaniu ze stanowiskiem Traktatu. Pojawienie się koncepcji systemu zdaniowego, w której 
„do rzeczywistości nie przykładam zdania jako miary, ale system zdań (System von Sätzen)", rodziło nowy problem - nie chodziło już o porównywanie zdania z rzeczywistością, o jej ustalenie przez zdanie na „tak” lub „nie”, lecz o rozważania gramatyczne określające, do jakiego systemu zdaniowego ono należy. Żeby tego dokonać, przede wszystkim należało określić sens zdania, do czego miała służyć metoda jego weryfikacji, która była wskazaniem sposobów i kontekstów użycia. Wittgenstein sam zresztą tak to później widzial:

Kiedyś zwykłem mówić w celu pokazania, jak określone zdanie jest używane, że dobrym pomysłem jest zapytać: „W jaki sposób dokonuje się weryfikacji takiego stwierdzenia?” Ale jest to tylko sposób jasnej prezentacji użycia słowa albo zdania [...]. Niektórzy obrócili to pytanie o weryfikację w dogmat - jak gdybym wysuwał jakąś teorię dotyczącą znaczenia (cyt. za Monk 2003: 311).

Słowa te dają też, jak sądzę, pewne wskazówki pozwalające rozstrzygnąć trudność, na którą wskazał Hymers (2005: 226). Chodziłoby o to, że w konsekwencji problemu wykluczania się zdań o kolorach Wittgenstein porzucił koncepcję atomizmu logicznego, ale dalej utrzymywał pogląd o konkluzywnej weryfikacji zdań elementarnych. Według Hymersa nie można jednak spójnie utrzymywać, że nie ma zdań elementarnych i że istnieje określony zbiór zdań efektywnie weryfikowalnych $\mathrm{w}$ doświadczeniu empirycznym, ponieważ zdania te połączone są z faktami, które je weryfikują ${ }^{11}$. Po pewnym czasie Wittgenstein uświadomił sobie tę trudność, odrzucił wtedy weryfikacjonizm. Z przedstawionych ustaleń wynika jednak, że Wittgenstein w swojej wersji weryfikacjonizmu z 1929 r. od początku skłaniał się do interpretacji gramatycznej. Być może przez jakiś czas nie oponował wobec interpretacji członków Koła Wiedeńskiego, którzy łączyli weryfikację z problemami empirystycznej teorii znaczenia, demarkacji, zdań protokolarnych itp., ale raczej nie był zainteresowany kwestiami epistemologicznymi. Zgodnie ze świadectwem Herberta Feigla mówił, że w ogóle nie był zainteresowany filozofią:

\footnotetext{
${ }^{11}$ Jakub Gomułka (por. 2016: 159) jest zdania, że trudność wskazaną przez Hymersa można wyjaśnić przede wszystkim tym, że koncepcja odwzorowania Wittgensteina jest subtelniejsza niż ujęcie pozytywistyczne pobrzmiewające w wykładni Hymersa. Chodziłoby o to, że przyporządkowanie elementów obrazu (zdania) przedmiotom jest wtórne względem sensu zdania, co jest realizacją zasady kontekstu Fregego. Dodatkowo weryfikacjonizm Wittgensteina jest, zdaniem Gomułki, bardziej systemowy, ma sens logiczny, a nie przyczynowy czy psychologiczny. Andreas Blank (2011: 630) uważa z kolei, że Wittgenstein nie dlatego porzucił weryfikacjonizm, że uznał go za niespójny z odrzuceniem logicznego atomizmu, ale dlatego, że starał się wypracować własną wersję weryfikacjonizmu niezależną od logicznego atomizmu. Blank podkreśla rolę dostrzegania różnych aspektów logicznej różnorodności zdań i faktów, starając się w ten sposób pokazać związek między weryfikacją a „widzeniem jako” (seeing-as).
} 
Czuł, że wszystko, co miał do powiedzenia, powiedział w Traktacie. Co więcej, stosunkowo rzadko udawało się nakłonić go do objaśnień tych czy innych niezrozumiałych bądź niejasnych fragmentów. Sam wydawał się raczej niepewny idei, które rozwinął podczas I Wojny Światowej (Feigl 1980: 63).

Kiedy jednak Wittgenstein powrócił do systematycznego uprawiania filozofii i zaczął ponownie rozważać problemy związane z Traktatem, jego myśli zmierzały już w innym kierunku niż idee Schlicka i jego współpracowników. Mimo odrzucenia atomizmu logicznego mógł zatem dalej mówić, że sensem zdania jest metoda jego weryfikacji, ponieważ nie łączył jej z empirystyczną teorią znaczenia, lecz z gramatyką.

Trudno też mówić o jakimś weryfikacjonistycznym okresie w rozwoju filozofii Wittgensteina. Lata 1929-1930 i następne to czas, kiedy dokonuje się raczej stopniowe odejście od stanowiska Traktatu i początek ksztaltowania się nowych poglądów na temat funkcjonowania języka. W tych czasach różnych prób i pomysłów interpretacja empiryczna niektórych ważnych problemów i pojęć sąsiaduje i przenika się z interpretacją gramatyczną. Tak właśnie było w wypadku pojęcia weryfikacji, które może być, z uwagi na tę dwuznaczność, potraktowane jako pojęcie okresu przejściowego, jako konceptualna zapowiedź nowego stanowiska. Nie bez racji więc Brian McGuinness dostrzegł w Wittgensteinowskim dyskursie o weryfikacji odejście od abstrakcyjnego traktowania języka w Traktacie i początek mówienia o konkretnych zjawiskach językowych (por. 2002: 180). Wittgenstein pojęcie weryfikacji stosował jeszcze w Dociekaniach filozoficznych, ale tam ma ono już wyraźnie gramatyczny charakter:

Pytanie o sposób i możliwości weryfikacji zdania jest tylko specjalną postacią pytania: „Jak to rozumiesz?”. Odpowiedź jest przyczynkiem do gramatyki zdania (Wittgenstein 200ob: §353).

\section{BIBLIOGRAFIA}

Blank A. (2011), Wittgenstein on Verification and Seeing-As, 1929-1932, „Inquiry” 54(6), 614-632. https://doi.org/10.1080/0020174X.2011.628081

Carnap R. (1963), Intellectual Autobiography [w:] The Philosophy of Rudolf Carnap, P. A. Schilpp (ed.), La Salle: Open Court, 3-42.

Dehnel P. (2014), Ludwig Wittgenstein. Teoria a terapia. Od „Traktatu” do „Dociekań filozoficznych", Warszawa: Wydawnictwo Naukowe PWN.

Dummett M. (1978), Truth and Other Enigmas, London: Duckworth.

Engelmann M. L. (2013), Wittgenstein's Philosophical Development, New York: Palgrave Macmillan. 
Feigl H. (1980), The Wiener Kreis in America [w:] Inquiries and Provocations: Selected Writings, 1929-1974, R. S. Cohen (ed.), Dordrecht: Reidel.

Glock H. J. (2001), Stownik Wittgensteinowski, tłum. M. Hernik, M. Szczubiałka, Warszawa: Spacja.

Gomułka J. (2016), Rachunek. Filozofia nauk formalnych i jej związek z koncepcja podmiotu we wczesnym i średnim okresie twórczości Ludwiga Wittgensteina, Kraków: Wydawnictwo Naukowe Uniwersytetu JP II.

Hacker P. M. S. (1981), The Rise and Fall of the Picture Theory [w:] Perspectives on the Philosophy of Wittgenstein, I. Block (ed.), Oxford: Basil Blackwell, 85-110.

Hacker P. M. S. (1986), Insight and Illusion: Themes in the Philosophy of Wittgenstein, Oxford: Clarendon Press.

Hacker P. M. S. (1996), Wittgenstein's Place in Twentieth-Century Analytic Philosophy, Oxford: Blackwell.

Hymers M. (2005), Going around the Vienna Circle: Wittgenstein and Verification, „Philosophical Investigation” 28(3), 205-234. https://doi.org/10.1111/j.1467-9205.2005. 00254.x

Janik A., Toulmin S. (1973), Wittgenstein's Viena, New York: Touchstone.

Koterski A. (2001), Weryfikacjonistyczne kryteria demarkacji $w$ filozofii nauki Kola Wiedeńskiego, Lublin: Wyd. Naukowe UMCS.

McGuinness B. (2002), Approaches to Wittgenstein, London: Routledge.

Medina J. (2002), The Unity of Wittgenstein's Philosophy, New York: State University of New York Press.

Misak C. J. (2005), Verificationism: Its History and Prospects, New York: Routledge.

Monk R. (2003), Wittgenstein. Powinność geniusza, tłum. A. Lipszyc, Ł. Sommer, Warszawa: Wydawnictwo KR.

Schlick M. (1969), Gesammelte Aufsätze 1926-36, Hildesheim: Georg Olms Verlag.

Shanker S. (2006), Wittgenstein and the Turning-Point in the Philosophy of Mathematics, London-New York: Routledge.

Waismann F. (1930), Logische Analyse des Wahrscheinlichkeitsbegriffs, „Erkenntnis” 1(1), 228-248. https://doi.org/10.1007/BFoo208618

Waismann F. (red.) (1984a), Wittgenstein und der Wiener Kreis, Werksausgabe, t. 3, Frankfurt am Main: Suhrkamp.

Waismann F. (1984b), Thesen [w:] Wittgenstein und der Wiener Kreis, Werksausgabe, t. 3, Frankfurt am Main: Suhrkamp, 233-263.

Wittgenstein L. (1997a), Tractatus logico-philosophicus, tłum. B. Wolniewicz, Warszawa: Wydawnictwo Naukowe PWN.

Wittgenstein L. (1997b), Kilka uwag o formie logicznej, tłum. M. Świerczyński, „Przegląd Filozoficzny - Nowa Seria” 5(1), 151-156.

Wittgenstein L. (1980), Wittgenstein's Lectures, Cambridge 1930-32, D. Lee (ed.), Oxford: Basil Blackwell.

Wittgenstein L. (2000a), The Big Typescript, Wiener Ausgabe, Bd. 11, hrsg. von M. Nedo, Wien-New York: Springer-Verlag.

Wittgenstein L. (200ob), Dociekania filozoficzne, tłum. B. Wolniewicz, Warszawa: Wydawnictwo Naukowe PWN.

Wrigley M. (1989), Origins of Wittgenstein's Verificationism, „Synthese” 78(3), 265-290. https://doi.org/10.1007/BFoo869351

Wright C. (1980), Wittgenstein on the Foundation of Mathematics, London: Duckworth.

Wright von G. H. (1982), Wittgenstein, Oxford: Basil Blackwell. 